УДК 621.039:504.064

B.A. Кондратюк, канд. техн. наук, ст. викл., ORCID 0000-0001-5035-311X

3.B. Іванов, магістрант, ORCID 0000-0002-5558-3392

Національний технічний університет України «Київський політехнічний інститут імені Ігоря

Сікорського»

\title{
ОЦІНКА РАДІАЦІЙНИХ НАСЛІДКІВ ПРИ ВАЖКИХ АВАРІЯХ НА АТОМНИХ ЕЛЕКТРИЧНИХ СТАНЦІЯХ
}

\begin{abstract}
Основною задачою радіаційного моніторингу АЕС є забезпечення радіаційної безпеки населення $i$, перш за все, в аварійних умовах. Розгляд запроектних аварій (3ПА) на атомних електростанціях $\epsilon$ найважливішим елементом принципу глибокоешелонованого захисту, який застосовується при забезпеченні радіаційної безпеки. В роботі виконано аналіз вимог законодавчих $і$ нормативних документів України щзодо призначення зони спостереження (3С) атомних електричних станџій і розглянуто пропозиції стосовно гармонізації ЗС з зонами аварійного планування, які мають бути встановлені згідно з рекомендаціями МАГАТЕ. Виконано консервативну оцінку доз внутрішнього та зовнішнього опромінення для гіпотетичної ЗПА на АEC за допомогою програмних продуктів HotSpot i ARGOS. Проведено оцінку можливості використання зон аварійного планування для Украӥнських АEC, $і$ встановлено, щзо це дасть можливість підвищити рівень захисту населення в умовах перебігу аварії.
\end{abstract}

Ключові слова: АЕС, запроектна аварія, захист населення, зона спостереження, прогнозування, радіаційна аварія.

Вступ

1977-й рік - рік народження української атомної енергетики. У промислову експлуатацію введено перший енергоблок Чорнобильської АЕС з реактором РВПК-1000. Зростаюча потреба в електроенергії, прагнення замінити теплові та гідроелектростанції на потужніші — атомні, сприяли ї швидкому будівництву [1]. На даний момент в світі експлуатується 450 енергоблоків, які мають встановлену електричну потужність 396,85 МВт [2], що складає близько 19 \% встановленої електричної потужності в світі [3]. При цьому, ще 55 енергоблоків знаходяться на стадії будівництва.

Проте, разом $з$ цим розвитком, використання ядерної енергетики створило серйозне питання щодо проблеми попередження можливих аварійних ситуацій на АЕС. Аварійні ситуації на АЕС, при яких відбувається пошкодження палива в активній зоні, згідно діючих нормативних документів, прийнято називати важкими аваріями [4]. Такі аварії можуть призводити до смертельних випадків, тяжких наслідків для здоров'я населення, психологічного впливу, а також можуть мати економічні і соціологічні наслідки для суспільства. До тяжких наслідків для здоров'я відносять тяжкі детерміновані і стохастичні ефекти, тобто радіоактивно-індуковані онкологічні захворювання. Ці наслідки можуть бути попереджені або пом'якшені шляхом невідкладного виконання дій по захисту населення і прийняття інших мір реагування.

Викиди в атмосферу радіоактивних матеріалів, які виходять з пошкодженої реакторної установки, утворюють хмару радіоактивних матеріалів і шлейф, який залишається після проходження хмари. В особливо важких аварійних ситуаціях дія цієї хмари на протязі декількох годин може стати причиною великої шкоди для здоров'я, або навіть смерті людей, які знаходяться на відстані близько $2-5$ км від АЕС [5], якщо захисні дії не будуть прийняті невідкладно. Ураження може відбуватися інгаляційним шляхом від радіоактивних речовин, які знаходяться в хмарі викиду, а також зовнішнім опроміненням від неї, або опроміненням від осаджених на землю радіонуклідів. Для того, аби міри по захисту від вказаних чинників були якомога ефективнішими, виконання захисних дій може бути потрібним ще до появи хмари викиду на певній ділянці, і тому, вони мають бути початі відразу ж після того, як умови на станції будуть визначені тяжкими (тобто відбуваються події, які призводять до фактичного аварійного викиду чи суттєвому ризику його виникнення, які потребують негайного виконання невідкладних захисних дій і інших мір реагування за межами майданчику АЕC) [5], не очікуючи результатів радіаційного моніторингу.

В межах 15 - 30 км, інгаляційне потрапляння радіонуклідів може призводити до зростання випадків онкологічних радіаційних захворювань, зокрема до раку щитовидної залози, спричиненого дією радіонуклідів йоду, який в значній мірі реалізується в ході аварії, і вносить один 3 найбільших вкладів в сумарну ефективну дозу при важких аваріях [6]. Аналогічним чином, для того, аби міри по захисту від можливих ракових захворювань були найбільш ефективними, захисні дії мають бути застосовані до появи хмари радіоактивного викиду і, відповідно до цього, не можуть бути реалізовані на основі екологічного моніторингу.

(C) В.А. Кондратюк, 3.В. Іванов, 2019 


\section{ISSN 1813-5420 (Print). Енергетика: економіка, технології, екологія. 2018. № 4}

\section{Мета та завдання}

Зробити оцінку можливості використання зон аварійного планування, які рекомендовані МАГАТЕ, для Українських АЕС шляхом моделювання викиду в оточуюче середовище радіоактивних речовин 3 енергоблоку при ЗПА та проведення оцінки доз внутрішнього та зовнішнього опромінення населення залежно від відстані до майданчику АЕС.

\section{Аналіз вимог щодо призначення зони спостереження АЕС}

Забезпечення безпечної роботи АЕС України відбувається за рахунок послідовної реалізації п'яти рівнів стратегії глибокоешелонованого захисту. Для захисту населення і персоналу АЕС під час виникнення ЗПА, застосовується четвертий рівень (управління ЗПА) та п'ятий рівень цієї стратегії (аварійна готовність та реагування). Реалізацію заходів, передбачених цими рівнями, забезпечує система аварійного реагування ДП «НАЕК «Енергоатом» на аварії та надзвичайні ситуації на АЕС. Система аварійного реагування (САР) - взаємопов'язаний комплекс технічних засобів і ресурсів, організаційних, технічних та радіаційногігієнічних заходів, здійснюваних ДП «НАЕК «Енергоатом» для запобігання або зниження радіаційного впливу на персонал, населення та навколишнє середовище в разі ядерної або радіаційної аварії на АЕС, а також з метою забезпечення цивільного захисту. Основними заходами САР щодо захисту населення передбачається, що захист населення необхідно проводити на територіях, які відносяться до ЗС.

Зона спостереження - територія, на якій можливий вплив радіоактивних скидів і викидів АЕС і на якій здійснюється радіаційний моніторинг вимірювання потужності поглинутої дози, визначення вмісту радіонуклідів у об'єктах навколишнього природного середовища, продуктах харчування тощо [4].

Для кожної АEC, відповідно до вимог [4], повинні бути визначені розміри санітарно-захисної зони (С33) і ЗС. Встановлення цих зон повинно обмежити радіаційний вплив на населення при нормальній експлуатації АЕС, при порушеннях нормальної експлуатації, при проектних і запроектних аваріях. Причому, С33 - територія навколо АЕС, в рамках якої заборонено проживання населення, встановлено обмеження на виробничу діяльність, яка не стосується до АЕС, а також здійснюється радіаційний контроль.

Тобто в умовах аварійної ситуації передбачається, що захист населення необхідно проводити в межах від СЗ3 до ЗС. Як відомо, розміри діючих С33 АЕС України становлять 2,7 км для ХАЕС і 2,5 км - для інших АЕС. А розміри $3 \mathrm{C}-30$ км.

Після аварії на АЕС «Фукусіма-1» було розроблено «Вимоги щодо визначення розмірів і меж зони спостереження атомної електричної станції» [7]. Цим документом встановлюється що розміри ЗС визначаються так, щоб при ЗПА, частота яких дорівнює або перевищує значення показників $10^{-5}$ piк $^{-1}$, дози опромінення населення на межі ЗС та за ії межами не перевищували критеріїв введення невідкладних контрзаходів (нижніх меж виправданості) - евакуації і йодної профілактики, а саме:

ефективна доза - 50 м3в;

доза на щитоподібну залозу:

у дітей - 50 мЗв;

у дорослих - 200 мЗв;

доза на шкіру - 500 м3в.

Проте аварія на АEC «Фукусіма-1» ще раз довела світовій спільноті що аварії на АЕС, навіть 3 найменшою вірогідністю виникнення, все ж трапляються. I тоді встановлені цим документом рівні контрзаходів, які не мають виконуватися на межі ЗС, в разі важкої аварії, можуть бути перевищені і за межею цієї зони. Також варто відмітити що нині в Україні прийнято те, що таблетки калій йодиду (КI), які мають першочергово використовуватись в разі важкої аварії (для проведення блокування щитовидної залози), наявні лише на території радіусом в 10 км від АЕС. Тож питання йодної профілактики на територіях розташованих далі залишається під питанням [8].

Згідно рекомендацій МАГАТЕ [5], в країнах які експлуатують АЕС, повинні бути встановлені так звані emergency planning zones - зони аварійного планування.

Аналогом С33 за розміром, але не за функціональною наповненістю, є зона запобіжних заходів (precautionary action zone) - територія, в межах якої на підготовчому етапі проводиться всебічна підготовка щодо оповіщення населення і початку прийняття населенням термінових захисних дій та інших заходів реагування, протягом години після оголошення загальної аварійної ситуації начальником зміни АЕС. Мета полягає в тому, щоб ініціювати захисні дії та інші заходи реагування до початку викиду, при якому потрібне здійснення захисних дій за межами майданчика об’єкта для запобігання важких детермінованих ефектів. Як бачимо з визначення терміну, на цій території дозволено проживання населення, що $є$ суттєвою різницею від СЗ3. МАГАТЕ рекомендує встановлювати розміри цієї зони радіусом від 3 до 5 км, в залежності від умов (наприклад, метеорологічних), притаманних майданчику АЕС.

Аналогом 3С є зона планування термінових захисних заходів (urgent protective action planning zone) територія, в межах якої на підготовчому етапі проводиться всебічна підготовка щодо оповіщення населення і початку прийняття населенням термінових захисних дій та інших заходів реагування, протягом години після оголошення загальної аварійної ситуації начальником зміни АЕС. Мета полягає в тому, щоб ініціювати 


\section{ISSN 1813-5420 (Print). Енергетика: економіка, технологіï, екологія. 2018. № 4}

захисні дії та інші заходи реагування до початку викиду, при якому потрібне здійснення захисних дій за межами майданчика об'єкта, або незабаром після нього але таким чином, щоб не затримувати виконання термінових захисних дій та інших заходів реагування в зоні запобіжних заходів. МАГАТЕ рекомендує встановлювати розміри цієї зони радіусом від 15 до 30 км, в залежності від умов притаманних майданчику AEC.

В зв'язку з вище описаним, вважається необхідним проведення розрахунку доз опромінення населення при ЗПА з важким пошкодженням палива.

\section{Розрахунок доз опромінення населення}

Для проведення розрахунку доз опромінення населення було використано два розрахункових коди: ARGOS i HotSpot.

HotSpot Коди HotSpot Health Physics були створені для забезпечення персоналу аварійного реагування та спеціалістів по плануванню дій в умовах надзвичайних ситуацій швидкого, портативного набору програмних засобів для оцінки інцидентів, пов’язаних з втратою контролю над радіоактивними матеріалами, зокрема і для обрахунку доз опромінення при аваріях на АЕС. Програмне забезпечення також використовується і для аналізу безпеки об’єктів, що працюють з ядерним матеріалом. Ознайомитись 3 моделями атмосферної дисперсії які використовуються в HotSpot можна за допомогою матеріалів представлених на сайті розробників даного коду [9].

ARGOS Система підтримки прийняття рішень ARGOS розроблена для забезпечення покращення антикризового управління при інцидентах, пов'язаних з аваріями на АЕС, об'єктах хімічної промисловості, аварій при перевезенні небезпечних об'єктів, застосування біологічної зброї та ін. Використання ARGOS полегшує прийняття рішень і покращує розуміння ситуації і обмін інформацією. В програмі можна проводити розрахунки як за користувацькими моделями метеорологічних умов, так і використовуючи реальні прогнози погоди i реальних умов у місці проходження інциденту. Атмосферна дисперсія радіонуклідів в ARGOS представлена в вигляді трьох різних моделей: мезомасштабна модель для невеликих відстаней RIMPUFF; модель дисперсії в межах населених пунктів URD; моделі атмосферної дисперсії на великі відстані (DERMA (Данія), MLDP0 (Канада), SNAP (Норвегія) і МATCH (Швеція)). Детальнішу інформацію можна отримати на сайті розробника [10].

Використавши обрані розрахункові коди було проведено розрахунок гіпотетичної аварії на XАEC. Розглядався один з можливих сценаріїв запроектної аварії на блоці ВВЕР-1000 [11] з гільйотинним розривом головного циркуляційного контуру з відмовою активних САО3 з накладанням незалежної відмови системи локалізації (незакриття арматури вентиляційної системи). Цілісність захисної оболонки при цьому зберігалася. Величину викиду радіонуклідів в атмосферу з АЕС наведено у таблиці 1. Умови протікання аварії було навмисне погіршено, але варто відмітити, що викид при розрахованій аварії є меншим, ніж при аваріях що розглядаються у [5] (зокрема, величина викиду радіонукліду ${ }^{131}$ I менша на два порядки).

Таблиця 1 - Активність викиду радіонуклідів в атмосферу з АЕС в обраному сценарії ЗПА

\begin{tabular}{|c|c|c|c|}
\hline Радіонуклід & $\begin{array}{c}\text { Активність } \\
\text { викиду, Бк }\end{array}$ & $\begin{array}{c}\text { Радіонуклід } \\
\text { викиду, Бк }\end{array}$ \\
\hline${ }^{131} \mathrm{I}$ & $4,396 \cdot 10^{15}$ & ${ }^{90} \mathrm{Sr}$ & $2,045 \cdot 10^{12}$ \\
\hline${ }^{132} \mathrm{I}$ & $3,805 \cdot 10^{15}$ & ${ }^{95} \mathrm{Zr}$ & $1,3 \cdot 10^{12}$ \\
\hline${ }^{133} \mathrm{I}$ & $1,0262 \cdot 10^{16}$ & ${ }^{95} \mathrm{Nb}$ & $4,44 \cdot 10^{12}$ \\
\hline${ }^{135} \mathrm{I}$ & $2,3435 \cdot 10^{15}$ & ${ }^{103} \mathrm{Ru}$ & $4,065 \cdot 10^{13}$ \\
\hline${ }^{85 \mathrm{~m}} \mathrm{Kr}$ & $9,6 \cdot 10^{15}$ & ${ }^{106} \mathrm{Ru}$ & $4,02 \cdot 10^{12}$ \\
\hline${ }^{85} \mathrm{Kr}$ & $5,85 \cdot 10^{14}$ & ${ }^{134} \mathrm{Cs}$ & $3,605 \cdot 10^{13}$ \\
\hline${ }^{87} \mathrm{Kr}$ & $1,47 \cdot 10^{16}$ & ${ }^{137} \mathrm{Cs}$ & $2,24 \cdot 10^{13}$ \\
\hline${ }^{132} \mathrm{Te}$ & $5,65 \cdot 10^{13}$ & ${ }^{138} \mathrm{Cs}$ & $5,8 \cdot 10^{14}$ \\
\hline${ }^{133} \mathrm{Xe}$ & $1,09 \cdot 10^{17}$ & ${ }^{140} \mathrm{Ba}$ & $4,37 \cdot 10^{13}$ \\
\hline${ }^{135} \mathrm{Xe}$ & $2,335 \cdot 10^{13}$ & ${ }^{144} \mathrm{Ce}$ & $3,06 \cdot 10^{13}$ \\
\hline
\end{tabular}

Крім активності викинутих радіонуклідів, визначальну роль у формуванні полів радіоактивного забруднення повітря і підстилаючої поверхні грають метеорологічні умови, які були на майданчику в момент проходження аварії на АЕС. В ході аналізу умов клімату і мікроклімату характерного для майданчику XАEC, були визначені такі характерні погодні умови (період - липень, нічний час): 
- інтенсивність приземної інверсії $-2,825^{\circ} \mathrm{C} / 100 \mathrm{~m}$;

- напрямок вітру: західний;

- швидкість вітру: $1 \mathrm{~m} / \mathrm{c}$;

- висота шару перемішування: 600 м;

- категорія стійкості атмосфери: D;

- опади: відсутні;

- температура повітря на висоті 10 м: $9,6{ }^{\circ} \mathrm{C}$.

Детальний опис того як проводиться розрахунок доз опромінення і атмосферного переносу і випадінь на поверхню грунту, згідно законодавства України, наведено у додатку 1 вимог [7].

Для даних метеоумов було оцінено величину ефективної дози опромінення на все тіло і величину дози опромінення щитовидної залози за допомогою програм HotSpot v3.0.2 i ARGOS v9.3 (розрахунок проведений з застосуванням мезомасштабної моделі атмосферної дисперсії радіонуклідів RIMPUFF). Відстань, на якій проводиться розрахунок - до 50 км від майданчика аварійної АЕС. На рисунку 1 - 2 показано величину ефективної дози опромінення на все тіло в залежності від відстані від АЕС. На рисунку 1 - дані з HotSpot приведені у вигляді графіку, а на рисунку 2 - дані з ARGOS представлені в тому вигляді, в якому їх надає програмний продукт. На рисунку 3 - 4 показано величину дози опромінення щитовидної залози в залежності від відстані від АЕС. На даних рисунках В1/B2/B3 - відстань 3/15/30 км від АЕС; Еф ефективна доза опромінення на все тіло, мЗв; Ев - нижня межа виправданості введення невідкладного контрзаходу - евакуація, мЗв; Ещз - доза опромінення на щитовидну залозу, мЗв; Дщз/Dщз - нижня межа виправданості проведення невідкладного контрзаходу - йодна профілактика у дітей/дорослих, мЗв.

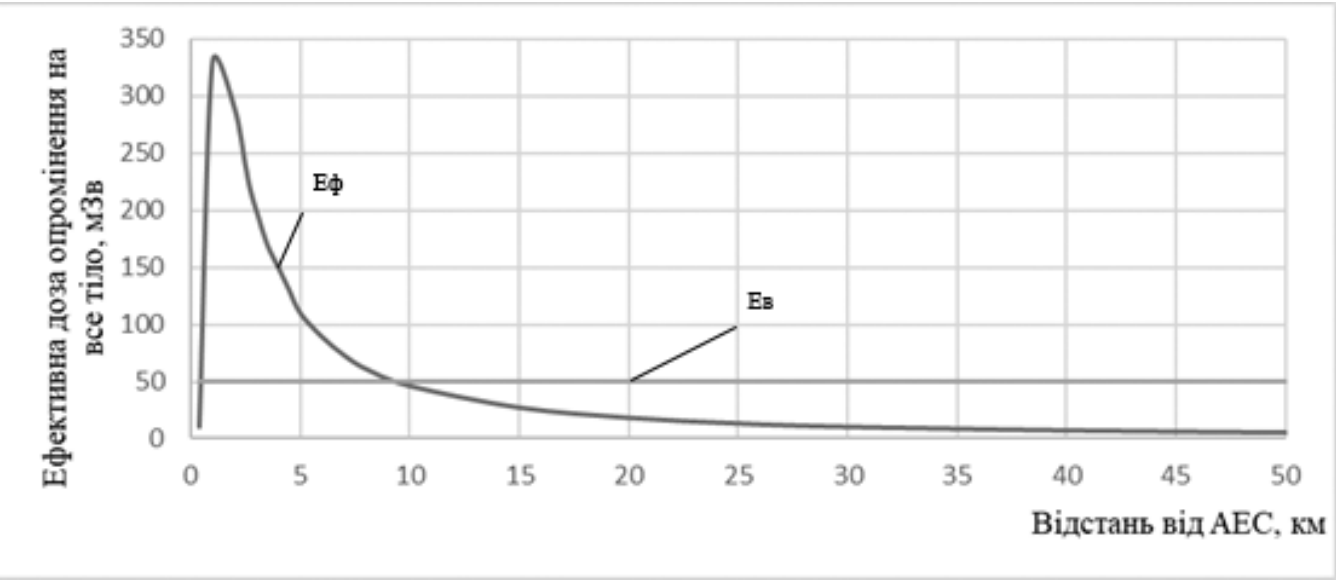

Рисунок 1 - Ефективна доза опромінення на все тіло для обраного сценарію ЗПА в залежності від відстані від майданчика AEC (HotSpot)

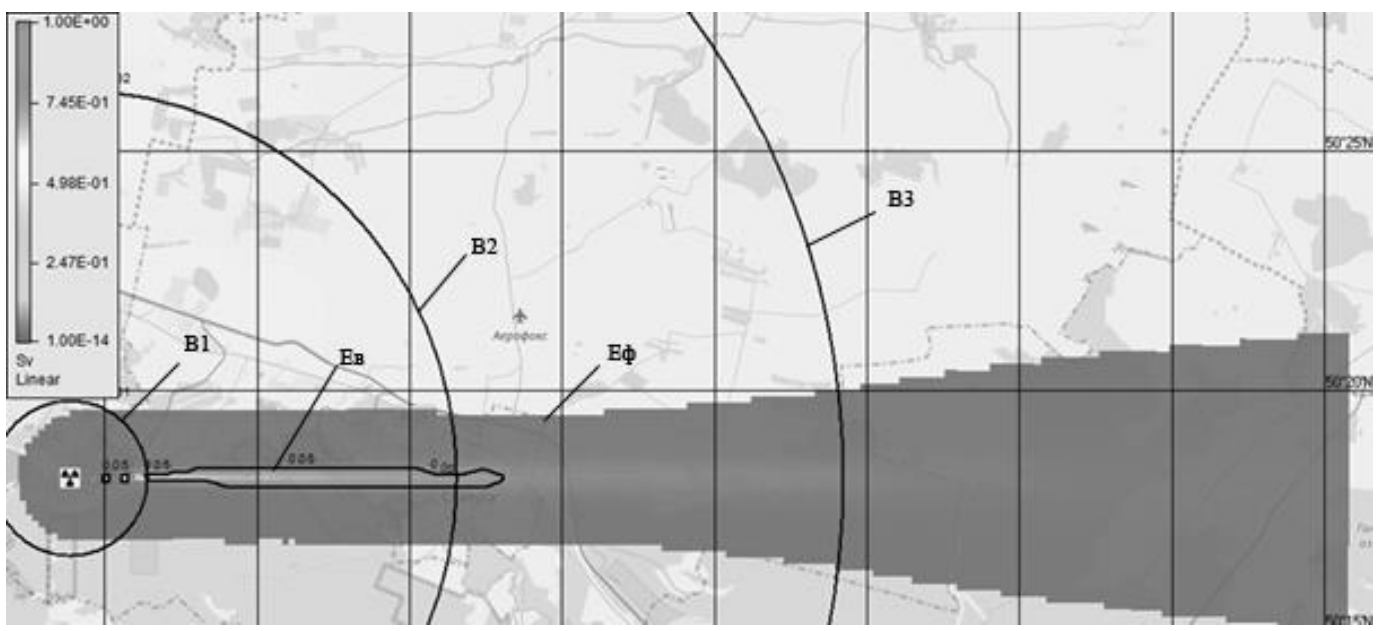

Рисунок 2 - Ефективна доза опромінення на все тіло для обраного сценарію ЗПА в залежності від відстані від майданчика AEC (ARGOS) 


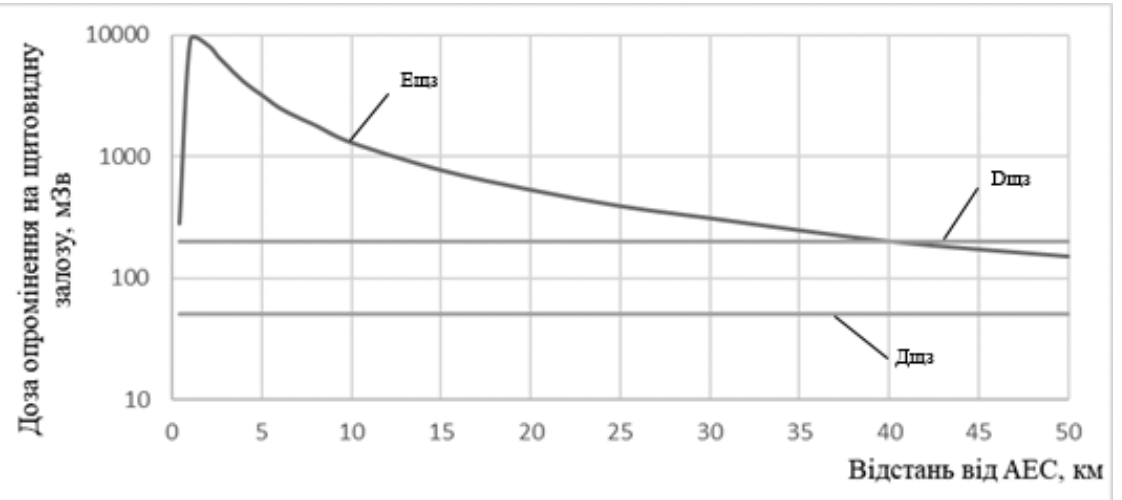

Рисунок 3 - Доза опромінення щитовидної залози для обраного сценарію ЗПА в залежності від відстані від майданчика AEC (HotSpot)

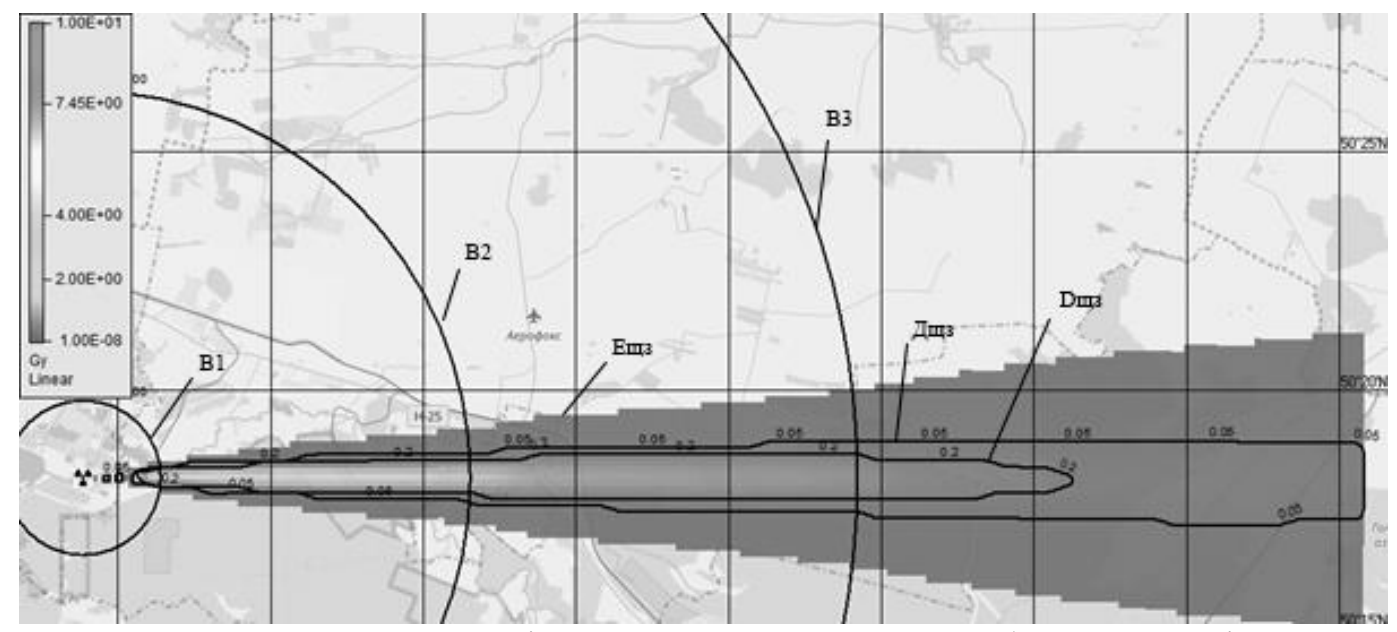

Рисунок 4 - Доза опромінення щитовидної залози для обраного сценарію ЗПА в залежності від відстані від майданчика AEC (ARGOS)

Як показують розрахунки, ефективна доза опромінення на все тіло для обраного сценарію ЗПА і для обраних метеоумов вказують на те, що евакуація населення буде необхідна на відстані 10 км (при розрахунку HotSpot) i 16 км (при розрахунку за допомогою ARGOS). Виходячи 3 того, що модель атмосферної дисперсії RIMPUFF прийнята для виконання розрахунків на відстані кількох сотень кілометрів, можна вважати що зона, радіусом в 15 км (включаючи м. Славута) може бути прийнята як зона планування термінових захисних заходів згідно рекомендацій МАГАТЕ. Також можна зауважити, що ця зона є меншою, ніж 3С, що дозволяє проводити дії в ній оперативніше, зокрема проводити ту ж евакуацію, бо територія, на якій вона має проводитися, буде значно менша. А згідно [5], іiі необхідно проводити по всім напрямкам від аварійної AEC, бо вітер може змінювати свій напрямок, а викид може бути не миттєвим, а тривалим.

Порівнюючи результати доз опромінення щитовидної залози помітно, що розрахунки HotSpot $\mathrm{i}$ ARGOS показують приблизно однаковий результат. На відстані до 40 км необхідне проведення йодної профілактики для дорослого населення, а для дітей буде необхідне на відстані більше ніж розрахункові 50 км. Цю відстань нинішня 3С не покриває, а як вже згадувалося раніше, таблетки КІ не розповсюджуються за межею відстані в 10 км від АЕС. В випадку проходження аварії подібного масштабу, або ж більшої, організувати йодну профілактику населення буде важко, якщо взагалі можливо. А з кожною годиною очікування початку йодної профілактики, іiі ефективність буде падати. Наведений приклад показує необхідність раннього введення йодної профілактики в випадку виникнення подібної ЗПА.

Тому, вважається доцільним запропонувати використовувати зону планування термінових захисних заходів радіусом в 15 км (і зосередити на ній увагу як на території, на якій необхідно першочергово проводити евакуацію), а таблетки КІ розповсюдити по території більшій ніж 40 км, можливо і по території всієї країни. І забезпечити можливість початку йодну профілактики населенням до приходу хмари викиду 3 AEC.

\section{Висновок}

В ході аналізу вимог до ЗС АЕС, було встановлено, що покладені на неї функції можуть не бути в повній мірі виконаними в випадку проходження ЗПА з великим викидом радіонуклідів в навколишню 


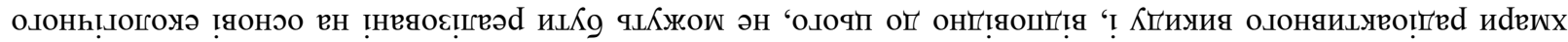

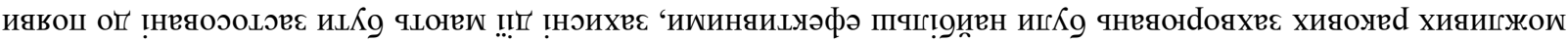

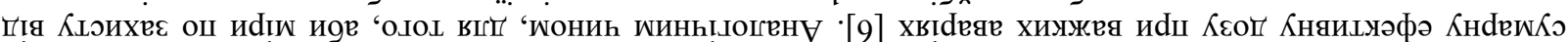

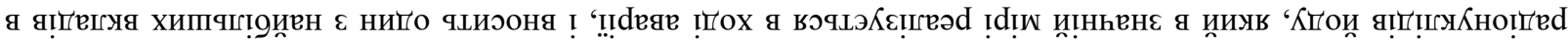

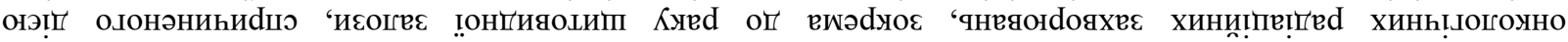

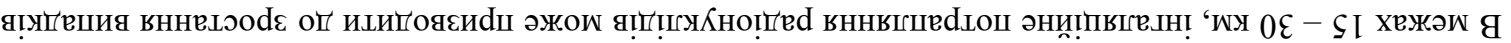

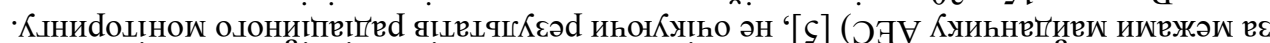

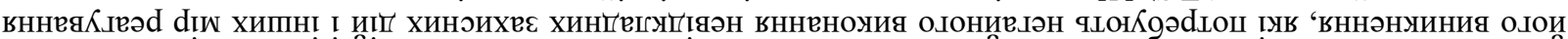

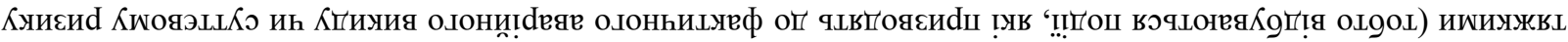

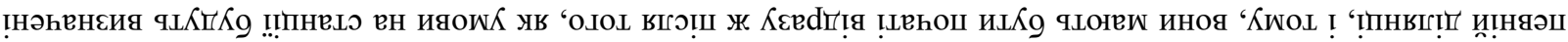

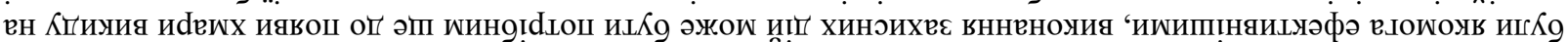

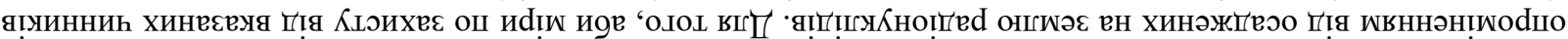

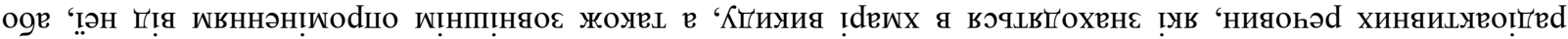

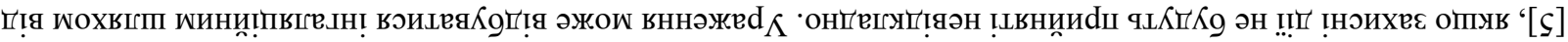

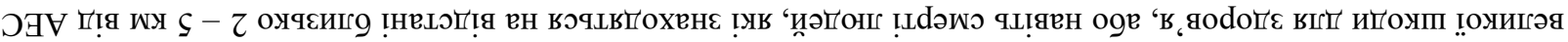

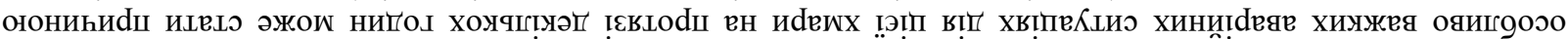

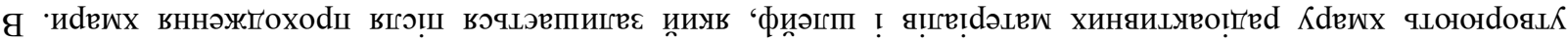

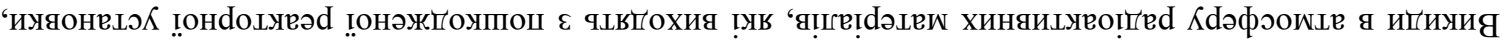

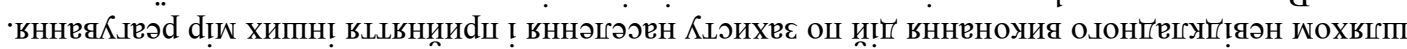

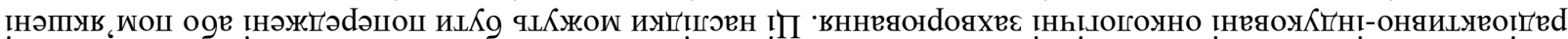

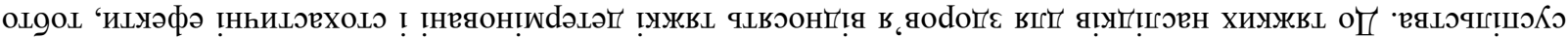

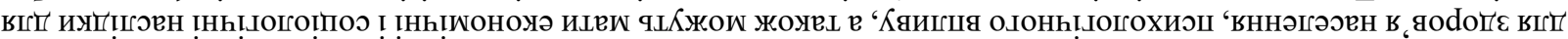

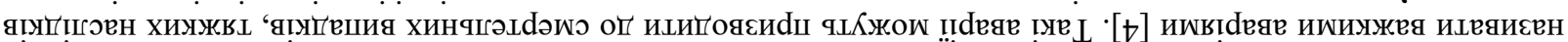

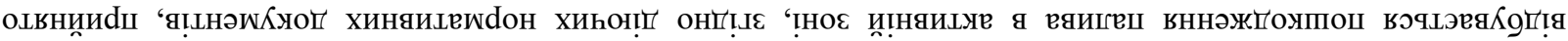

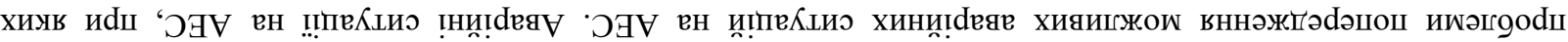

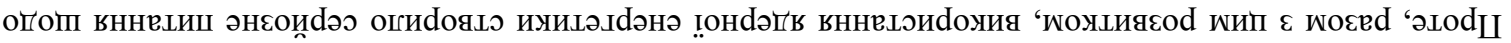

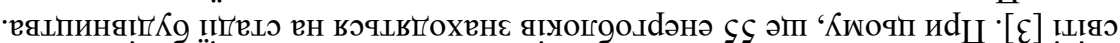

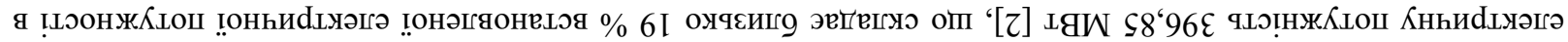

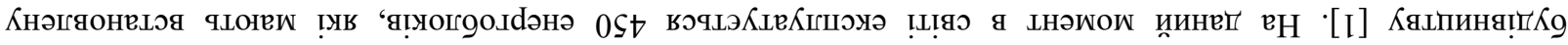

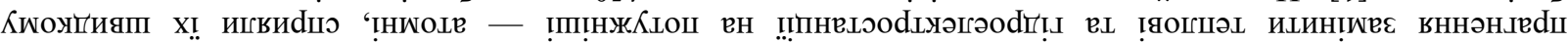

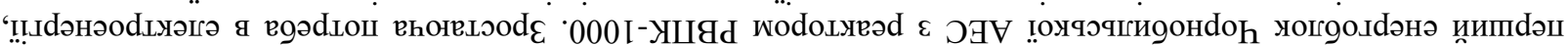

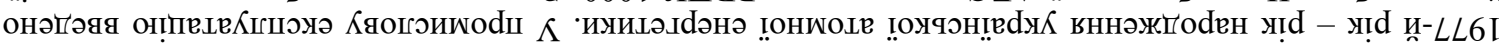

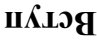

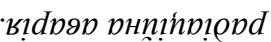

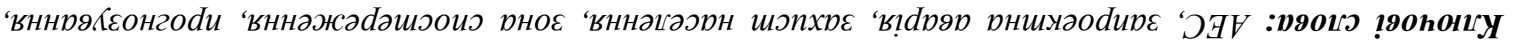

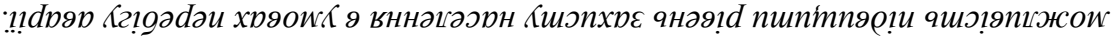

qшэре әй от 'онацяонршоя ! 'Ј Куніпо онараяод

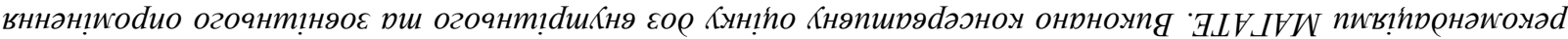

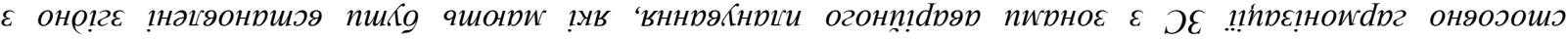

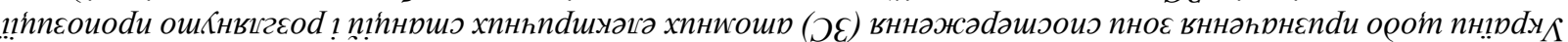

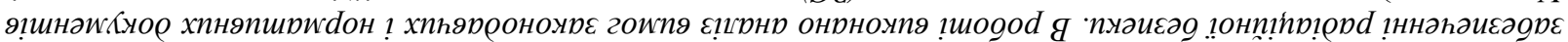

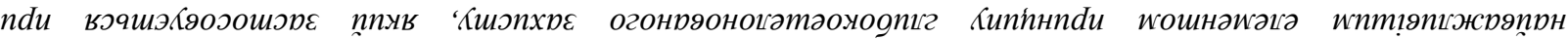

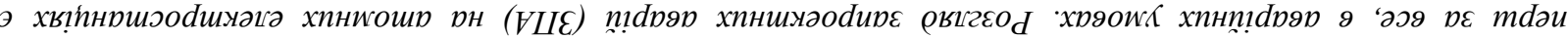

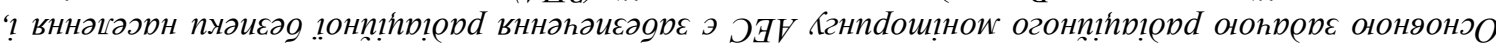

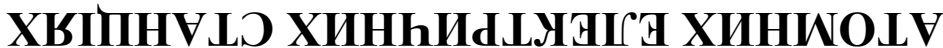

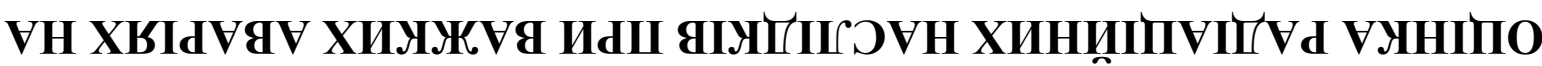

«оцоутодоч!

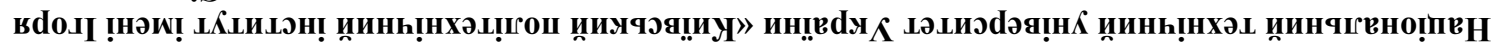

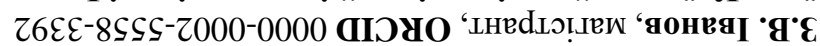

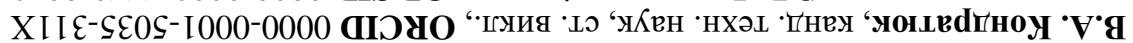


середовище. Було запропоновано використати зони аварійного планування, які згідно рекомендацій МАГАТЕ мають бути встановлені на АЕС.

Для розрахунку доз опромінення було використано програмні продукти HotSpot та ARGOS 3 мезомасштабною моделлю атмосферної дисперсії радіонуклідів RIMPUFF. Варто відміти що код HotSpot $\epsilon$ більш простим в користуванні, а також є безкоштовним. Проте модель радіоактивного викиду в ньому задається одиничним набором радіонуклідів, які в один момент виходять з точки початку розрахунку. До того ж, метеоумови задаються сталими на весь період розрахунку, що не завжди відповідає реальним умовам. Модель RIMPUFF дозволяє задавати викид декількома інтервалами і з змінними погодними умовами (можливо використовувати як поточний прогноз погоди, так і попередньо задумані метеоумови). Результат, який представляє ARGOS є наочним і точнішим, проте і потребує значних обчислювальних потужностей, і ліцензованого програмного забезпечення.

Для обраної ЗПА було сформовано рекомендації щодо перегляду ЗС в напрямку ії заміни на зону планування термінових захисних заходів (радіусом в 15 км замість 30 км) і створення додаткової зони, в якій необхідно зберігати, або попередньо розповсюдити препарати, за допомогою яких можливо буде провести йодну профілактику.

\section{Список використаної літератури}

1. Атомная энергетика по странам (загальнодоступна багатомовна інтернет-енциклопедія). [Електронний ресурс]. - Режим доступу: https://ru.wikipedia.org/wiki/Атомная_энергетика_по_странам.

2. The Database on Nuclear Power Reactors. [Електронний ресурс]. - Режим доступу: https://pris.iaea.org/pris.

3. Energy, electricity and nuclear power estimates for the period up to 2050, 2018 Edition, Vienna: IAEA, 2018. $-150 \mathrm{p}$.

4. НП 306.2.141-2008. Загальні положення безпеки атомних станцій : Затвердж. наказом Держатомрегулювання 19.11.2007 № 162; зареєстр. в М-ві юстиції України 25.01.2008 за № 56/14747. — К. : Держ. ком. ядерного регулювання України, 2008. - 59c.

5. Actions to Protect the Public in an Emergency due to Severe Conditions at a Light Water Reactor. Viena: International Atomic Energy Agency, 2013. - 159 p. - (IAEA Emergency Preparedness and Response (EPR) series, EPR-NPP-PPA (2013)).

6. Превентивная подготовка информационного обеспечения - основное концептуальное положение аварийного радиационного мониторинга территории влияния АСС / Б.С. Пристер, Е.К. Гаргер, Н.Н. Талерко, В.Д. Виноградская // Проблеми безпеки атомних електростанцій і Чорнобиля. - 2013. - Вип. 21. С. $91-98$.

7. НП 306.2.173-2011. Вимоги щодо визначення розмірів і меж зони спостереження атомної електричної станції : Затвердж. наказом Держатомрегулювання України та МОЗ України від 07.11.2011 № 153/766; зареєстр. в М-ві юстиції України 24.11.2011 за № 1343/20081 // Офіційний вісник України. —2011. — № 94. - Стор. 276. - Стаття 3444. — Код акту 59384/2011.

8. Актуальні проблеми йодної профілактики в Україні на випадок радіаційної аварії на AEC. Аналітична записка. [Електронний ресурс]. - Режим доступу: http://www.niss.gov.ua/articles/1379/.

9. HotSpot. Health Physics Codes for the PC. [Електронний ресурс]. - Режим доступу: https://narac.llnl. gov/hotspot.

10. PDC-ARGOS. CBRN Crisis Management. [Електронний ресурс]. - Режим доступу: https://pdcargos.com.

11. ТЭО. Том 13.3. Оценка воздействий на окружающую среду (ОВОС). Общая характеристика энергоблоков. 43-814.203.004.ЭО.13.03. КИЕП, 2011 г. - Ст. 128. [Електронний ресурс]. - Режим доступу: http://www.archive.energoatom.kiev.ua/ru/file_viewer.html?id=1d2219827363abd14927be02f7860bbe.

\section{УДК 621.039:504.064}

В.А. Кондратюк, канд. техн. наук, ст. преп., ORCID 0000-0001-5035-311X

3.B. Іванов, магистрант, ORCID 0000-0002-5558-3392

Национальный технический университет Украины «Киевский политехнический институт имени ОЦЕНКА РАДИАЦИОННЫХ ПОСЛЕДСТВИЙ ПРИ ТЯЖЕЛОЙ АВАРИИ НА АТОМНОЙ ЭЛЕКТРОСТАНЦИИ

Основной задачей радиационного мониторинга АЭС является обеспечения радиационной безопасности населения, прежде всего в аварийных условиях. Рассмотрение запроектных аварий (ЗПА) на атомных электростанциях является важнейшим элементом принципа глубокоэшелонированной защиты, применяемой при обеспечении радиаџионной безопасности. В работе выполнен анализ требований 
середовище. Було запропоновано використати зони аварійного планування, які згідно рекомендацій МАГАТЕ мають бути встановлені на АЕС.

Для розрахунку доз опромінення було використано програмні продукти HotSpot та ARGOS 3 мезомасштабною моделлю атмосферної дисперсії радіонуклідів RIMPUFF. Варто відміти що код HotSpot $\epsilon$ більш простим в користуванні, а також є безкоштовним. Проте модель радіоактивного викиду в ньому задається одиничним набором радіонуклідів, які в один момент виходять з точки початку розрахунку. До того ж, метеоумови задаються сталими на весь період розрахунку, що не завжди відповідає реальним умовам. Модель RIMPUFF дозволяє задавати викид декількома інтервалами і з змінними погодними умовами (можливо використовувати як поточний прогноз погоди, так і попередньо задумані метеоумови). Результат, який представляє ARGOS є наочним і точнішим, проте і потребує значних обчислювальних потужностей, і ліцензованого програмного забезпечення.

Для обраної ЗПА було сформовано рекомендації щодо перегляду ЗС в напрямку ії заміни на зону планування термінових захисних заходів (радіусом в 15 км замість 30 км) і створення додаткової зони, в якій необхідно зберігати, або попередньо розповсюдити препарати, за допомогою яких можливо буде провести йодну профілактику.

\section{Список використаної літератури}

1. Атомная энергетика по странам (загальнодоступна багатомовна інтернет-енциклопедія). [Електронний ресурс]. - Режим доступу: https://ru.wikipedia.org/wiki/Атомная_энергетика_по_странам.

2. The Database on Nuclear Power Reactors. [Електронний ресурс]. - Режим доступу: https://pris.iaea.org/pris.

3. Energy, electricity and nuclear power estimates for the period up to 2050, 2018 Edition, Vienna: IAEA, 2018. $-150 \mathrm{p}$.

4. НП 306.2.141-2008. Загальні положення безпеки атомних станцій : Затвердж. наказом Держатомрегулювання 19.11.2007 № 162; зареєстр. в М-ві юстиції України 25.01.2008 за № 56/14747. — К. : Держ. ком. ядерного регулювання України, 2008. - 59c.

5. Actions to Protect the Public in an Emergency due to Severe Conditions at a Light Water Reactor. Viena: International Atomic Energy Agency, 2013. - 159 p. - (IAEA Emergency Preparedness and Response (EPR) series, EPR-NPP-PPA (2013)).

6. Превентивная подготовка информационного обеспечения - основное концептуальное положение аварийного радиационного мониторинга территории влияния АСС / Б.С. Пристер, Е.К. Гаргер, Н.Н. Талерко, В.Д. Виноградская // Проблеми безпеки атомних електростанцій і Чорнобиля. - 2013. - Вип. 21. С. $91-98$.

7. НП 306.2.173-2011. Вимоги щодо визначення розмірів і меж зони спостереження атомної електричної станції : Затвердж. наказом Держатомрегулювання України та МОЗ України від 07.11.2011 № 153/766; зареєстр. в М-ві юстиції України 24.11.2011 за № 1343/20081 // Офіційний вісник України. —2011. — № 94. - Стор. 276. - Стаття 3444. — Код акту 59384/2011.

8. Актуальні проблеми йодної профілактики в Україні на випадок радіаційної аварії на AEC. Аналітична записка. [Електронний ресурс]. - Режим доступу: http://www.niss.gov.ua/articles/1379/.

9. HotSpot. Health Physics Codes for the PC. [Електронний ресурс]. - Режим доступу: https://narac.llnl. gov/hotspot.

10. PDC-ARGOS. CBRN Crisis Management. [Електронний ресурс]. - Режим доступу: https://pdcargos.com.

11. ТЭО. Том 13.3. Оценка воздействий на окружающую среду (ОВОС). Общая характеристика энергоблоков. 43-814.203.004.ЭО.13.03. КИЕП, 2011 г. - Ст. 128. [Електронний ресурс]. - Режим доступу: http://www.archive.energoatom.kiev.ua/ru/file_viewer.html?id=1d2219827363abd14927be02f7860bbe.

\section{УДК 621.039:504.064}

В.А. Кондратюк, канд. техн. наук, ст. преп., ORCID 0000-0001-5035-311X

3.B. Іванов, магистрант, ORCID 0000-0002-5558-3392

Национальный технический университет Украины «Киевский политехнический институт имени ОЦЕНКА РАДИАЦИОННЫХ ПОСЛЕДСТВИЙ ПРИ ТЯЖЕЛОЙ АВАРИИ НА АТОМНОЙ ЭЛЕКТРОСТАНЦИИ

Основной задачей радиационного мониторинга АЭС является обеспечения радиационной безопасности населения, прежде всего в аварийных условиях. Рассмотрение запроектных аварий (ЗПА) на атомных электростанциях является важнейшим элементом принципа глубокоэшелонированной защиты, применяемой при обеспечении радиаџионной безопасности. В работе выполнен анализ требований 


\section{ISSN 1813-5420 (Print). Енергетика: економіка, технології, екологія. 2018. № 4}

законодательных и нормативных документов Украины относительно назначения зонь наблюдения (ЗН) атомных электрических станций и рассмотрены предложения по гармонизаџии ЗН с зонами аварийного планирования, которые должны быть установлены в соответствии с рекомендациями МАГАТЭ. Выполнена консервативная оценка доз внутреннего и внешнего облучения для гипотетической ЗПА на АЭС c помощью программных продуктов HotSpot и ARGOS. Проведена оченка возможности использования зон аварийного планирования для Украинских АЭС, и установлено, что это позволит повысить уровень защить населения в условиях протекания аварии.

Ключевые слова: АЭС, запроектная авария, защита населения, зона наблюдения, прогнозирование, радиационная авария.

\section{Kondratyk, Cand. Sc. (Eng.), Assis. Prof., ORCID 0000-0001-5035-311X Z. Ivanov, Msc., ORCID 0000-0002-5558-3392 ASSESSMENT OF RADIATION CONSEQUENCES OF SEVERE ACCIDENT AT NUCLEAR POWER} PLANT

The main task of the NPP radiation monitoring is to ensure the radiation safety of the population, especially in emergency conditions. Consideration of beyond design basis accidents at nuclear power plants is the most important element of the principle of defense in depth applied in ensuring radiation safety. The article analyzes the requirements of legislative and regulatory documents of Ukraine regarding purposes of observation areas of nuclear power plants and considers proposals for harmonization of observation areas with emergency planning zones, which should be used in accordance with the recommendations of the IAEA. The calculation of possible internal and external exposure for a hypothetical beyond design basis accidents at nuclear power plants was performed using HotSpot and ARGOS software products. An assessment of the possibility of using emergency planning zones for Ukrainian NPPs has been carried out, and it has been established that this will increase the level of protection of the population in emergency conditions.

Keywords: NPP, beyond design basis accident, protection of the population, observation area, forecasting, radiation accident.

\section{References}

1. "Nuclear power by country", available at: https://en.wikipedia.org/wiki/Nuclear_power_by_country.

2. "The Database on Nuclear Power Reactors" available at: https://pris.iaea.org/pris.

3. International Atomic Energy Agency. Energy, electricity and nuclear power estimates for the period up to 2050, 2018 Edition. Vienna: International Atomic Energy Agency; 2018. 150 p.

4. NP 306.2.141- 2008, General Safety Provisions for Nuclear Power Plants [Obschie polozheniia bezopasnosti atomnykh stantsii], State Nuclear Regulatory Inspectorate of Ukraine, Kyiv (2008), 58 p. (Rus)

5. International Atomic Energy Agency. Actions to Protect the Public in an Emergency due to Severe Conditions at a Light Water Reactor. (IAEA Emergency Preparedness and Response (EPR) series, EPR-NPP-PPA (2013)). Vienna: International Atomic Energy Agency; 2013. 159 p.

6. B. S. Prister, E. K. Garger, M. M. Talerko, V. D. Vinogradska. [Preventive preparation of information maintenance - the main conceptual of emergency radiation monitoring of territories of NPP]. Problems of nuclear power plants' safety and of Chornobyl. 2013;(21):91-98.

7. NP 306.2.173-2011, Requirements for Determining the Sizes and Boundaries of Observation Areas of Nuclear Power Plants [Vymohy do vysnachennya rozmiriv and mezh zony sposterezhennya atomnoi elektrychnoi stantsii], Ofitsiinyi Visnyk Ukrainy (2011), No. 94, 276 p. (Ukr)

8. "Actual problems of iodine prophylaxis in Ukraine in case of radiation accident at NPP. Analytical note", available at: http://www.niss.gov.ua/articles/1379/.

9. "HotSpot. Health Physics Codes for the PC", available at: https://narac.llnl.gov/hotspot.

10. "PDC-ARGOS. CBRN Crisis Management.", available at: https://pdc-argos.com.

11. “43-814.203.004.ЭO.13.03. Feasibility Study. Chapter 13.3. Environmental Impact Assessment (EIA). General characteristics of power units. KIEP. 2011. - 128 p.” available at: http://www.archive.energoatom.kiev.ua /ru/file_viewer.html?id=1d2219827363abd14927be02f7860bbe. 